\title{
Through Women's Eyes: A Study of Vulnerability in 2015 Earthquake
}

Devi Gurung

\begin{abstract}
The effects of disasters as being differentiated across the spectrum of sociological categories have received wider acceptance through a number of scholarly articles. In the context of Nepal, a disaster prone country, the social science scholars came to their big awakening of the long established anecdotes only after Gorkha earthquake hit the country in 2015. This qualitative research, conducted through a case study in earthquake hit Gamchha in outskirts of Kirtipur town in Kathmandu, where fifteen female respondents were interviewed in long form, puts itself in a gap, left out by the previous scholars who largely missed the post-disaster experiences of the women corresponding to their different social categories and contexts. It takes a close-up of a nuanced and a step-wise process to flesh out gender, disaster as being sociologically biased towards women, and in due course targets the gap within the category of women through the gendered perspective of disaster. Showing the pointers to the existing gaps in the approach toward the disasters, the differentiated policies are intrinsically prescribed to address the demands of women depending upon their positionality in the social landscape.
\end{abstract}

Keywords: disaster, Gorkha earthquake, Nepal, post-disaster experience

\section{Introduction}

On April 25, 2015, an earthquake measuring 7.8 magnitude on Richter scale, its epicenter at Barpak village in Gorkha, which is named Gorkha earthquake. Disaster, emanated from natural and geological phenomena, as tectonic collisions under our feet culminating into an earthquake, which humans are still unable to make correct predictions of their comings, doesn't always equally affect the people under its scope so as to long for its sociological analysis. A sociological account of disaster excavates differential impacts corresponding to gender, caste, ethnicity, class, geography and disability among others, and their exposure to pre-disaster risks which generally metamorphoses unto impacts. Prior to 1990s, literatures on disaster overlooked the gendered dimensions (Enarson and Morrow, 1998). In 1994, Enrico L Quarantelli, an US sociologist specializing on disaster, included gender as one of the facets of disaster, which garnered researchers' wide attention (see: Quarantelli, 1998). In addition to the contributions sympathetic to the plight of women, feminists have been long accusing the existing literatures for conspicuously putting gender along with several marginalized social categories under the erasure of socalled positivistic, quantitative approach, and have been seriously pointing out to the "gender neutral" portrayal of disasters (Finlay, 1998). In the 1990s, scholastic articles rightly pointed out the paucity of the "gendered terrain of disaster" whilst addressing how the vulnerability is rooted in gender, and how it is socially constructed through a number of factors anchored to gender, inclusive of familial structure, land ownership, domestic violence and poverty (Enarson and Morrow, 1998); the relationship between "pervasiveness and perniciousness" of social inequalities and hazard vulnerability in the disaster process (Bolin, 2007); and, radically calling the "preparedness, response, recovery, mitigation" formula into question, and a need to replacing it with a taxonomy of points dedicated to women (Fothergill, 1998).

This study puts women, as a broad category of social division, at the center stage of disaster process, and seeks to look at how women and girls navigate through the time of cataclysms. Through the longish interviews and observations, this study explores the long women's experiences during the initial rescue and relief, of how they responded and how they were responded toward, rehabilitation, and their socioeconomic statutes correlating to the overall process. Into the bargain, the data generated aforementioned is put into a larger and overarching structural contexts and features of the Nepali society.

A combined effect of rugged geography, high seismicity, concentrated precipitation, and global climate change makes Nepal one of the most disaster prone countries (Nepal et al, 2018). Located in-between the Indian and Tibetan tectonic plates makes the country susceptible to seismic movement from time to time. The 1934 earthquake, recognized as Nepal-Bihar Earthquake, is greatly detailed in the Great Earthquake of Nepal, 1934 [trans. Nepalko Maha Bhukampa, 1990] by Major General Brahma Sumsher Rana. The earthquake was not merely a powerful jolt with its damaging aftermath, but a memory device through which Nepalis remained awakened to the

\section{This work is licensed under the Creative Commons CDevi Gurung}

Devi Gurung: Namaste Homes, a German Organization, in Kathmandu.

Email:devigurung25@gmail.com/https://orcid.org/0000-0002-8434-3718 
fact that their country has been ever vulnerable to the earthquake for a long time (Adhikari, 2015). According to Brahma Sumsher Rana, the 1934 earthquake claimed 8,519 lives with 4, 669 women and girls; and, brought down 207, 740 houses into debris. The recent one that struck on April, 2015, according to government statistics, took away 8, 790 lives with left 23, 000 with injuries, some fatal, and demolished 500, 000 houses (GoN, 2015). In total, the earthquake affected nearly 8 million people, a third of the country's population. Spatially, 14 out of 75 districts were pronounced "crisis hit" with other 17 as partially affected. In the same event, women and girls accounted for 55 percent of total deaths, thus opening up their overt, slightly higher vulnerability.

Earthquake discharges an assortment of experiences corresponding to its usual phases-rescue, relief and rehabilitation-all being influenced by the sociological matrices, hence mirroring the social makeup of the affected society. Reviewing hundreds of data and reports, Fothergill (1998) concludes that women are more prone to ill effects of disaster through their high exposures to risk, lack of information, high mortality and greater psychological impacts. According to Cannon (1994), women are specifically more vulnerable during disasters because of their social, economic and cultural standings, and, even, exacerbated vulnerabilities when gender coalesces with caste, class, ethnicity, education level and age among other categories. In disaster literatures, social vulnerability refers to how social, cultural and economic contexts influence the extent to which people and communities experience the impact of disaster differently (Laska et al, 2007). The abovementioned literatures indicate assorted attributes and conditions such as class, caste, gender, educational level and physical and mental abilities put people in the differential risks. These categories are often interrelated and correlated. Clearly, the impacts of disasters are always social, cultural and economic events which are linked to who we are, how we live, how we structure, and how we maintain our society. Severity on the impact of disaster towards depends on the level of gender inequality in the given society. Within women, poor people are even more vulnerable, their vulnerabilities protract to the rehabilitation phase (Fothergill, 1998). The poor, widows, elderlies and homeless women suffer the brunt of the disaster the most. The women from the disadvantaged and marginalized communities are more likely to reside in vulnerable quarters with weak housing structures that open a can of worms - overt and covert - during the time of disaster. Also, women in poor conditions, with limited access to resources, put them in higher risk, and in turn take a longer time to reshape after the disaster.

Consequently, in this study, social, economic and cultural factors are taken into consideration for the purposed sociological study of vulnerability leading to disaster. In this paper, I have explored how women and girls navigate the process of earthquake, and how women of certain categories have to suffer the brunt of disaster the most in a local setting owing to their corresponditial social and economic statuses.
The purpose of this study is to show how women and girls are more vulnerable than men during disasters because of a fact that the existing bureaucracy of disaster remains to be masculine to the worst and gender neutral to the best, and touches upon a gap in disaster research of Nepal, fleshing out the intracategorical distinctions (McCall, 2005) which are long been avoided. The differentiated experiential plight of women in disaster as compared to men (Crenshaw, 1989) has been posited as a fact, wherefrom this study moves on to foreground the categorical specificities, within the group of women, which make further impacts during the disasters. In the second, I have not made comparisons between groups; rather I have put forth the findings in their own right.

\section{Methods and Materials}

Research methodology is a coherent set of ideas about philosophy, methods and data underpinning the research process and the production of knowledge (McCall, 2005). This qualitative study has employed descriptive and interpretative approach to incorporate the experiences of different set of women into the existing disaster discourse.

Qualitative methods are more apt in drawing theoretical insights and methodological principles to make sociology of disaster more reflective to world conditions and more open to social organization of communities in crisis (Enarson and Philips, 2008). I have embraced descriptive and interpretative approach to fulfill the objective as I try to find out the answer for "why and how" (Porta and Keating, 2008) in a seemingly abstract social field.

The study was conducted in Gamchha Tole of Kirtipur Municipality during fieldwork of master's thesis of sociology. Outskirts of Kirtipur, which face the southern hills of the Kathmandu Valley, were hit hard by the 2015 earthquake. Gamchha was among them, where almost all the mud houses of ethnic Newars and other communities were demolished. Gamchha is located at a walking distance of half an hour from Kirtipur Bazaar. Though being close to the urban locale, Gamchha seemingly is a rural location with no concrete buildings, and the nearest public transport is at the distance of fifteen minutes' walk to the north. In the selection of field, I had made several considerations. With limited resource and time, I had to choose an area which could supply me with ample information regarding the issues faced by women in earthquake affected areas. On one hand, Gamchha was close to my Tribhuvan University dormitory, where I was staying during the time of this research, and on the other hand, it was uniquely suffered by the earthquake unlike its urban vicinity.

This study notes that all 135 houses in Gamchha were brought down or cracked by the earthquake, and grippingly no one succumbed to death. All the 135 houses were demolished, and everyone got the red card. The location is a heterogeneous community with diverse caste groupsBrahmin, Giri/Puri, Chhetri, Putuwar Newars, Dalits and Tamang - sharing a relatively small territory.

I started this research by interviewing female respondents of Gamchha, fifteen of the long interviews are 
considered in writing of this paper. I have used unstructured, in-depth interviews with the respondents with a prior key informant interview. I did talk to women from poor, lower middle and higher middle class. I have interviewed women between the ages of 12 and 72. In selection of respondents, I took considerations of women and girls of menstruating age, pregnant and lactating mothers along with female headed households.

The key informant helped me find the respondents. Also, after each interview, I asked my respondent to point out the other probable respondent who would talk to me about their experiences. As a woman myself, it was more comfortable for me to ask, and to answer for my respondents. The interviews were both, long and short. I asked them to describe their experiences during the different phases - rescue, relief and rehabilitation - of earthquake. The interviews spanned on/off the topics as I kept on putting less urgency to start answering the specific questions. The interviews meandered on several directions from the mundane talks of everyday life in likes of what they ate for lunch, to the talks that slowly crept unto the check listed items - what kind of hardship they faced during and after the earthquake.

The interviews were conducted on the practically, matter-of-factly basis. Sometimes I would start by asking about their newly built homes or those under construction which would readily enter to the several topics related to the earthquake. At other times, we would talk about the harvest. During interviews, some would talk about other family or community members who had faced severe hardship after the earthquake, and would introduce me to them. There were respondents who would readily pour their sayings, and other taciturn. After several interviews, when I felt the data was saturated, to an extent that this study had aimed for, I transcribed and translated all the interviews. As I had interviewed several women and girls, I shortened the number of interviews to fifteen depending upon their pertinence to this research. I have dismissed the interviews which were marked by sheer irrelevance, duplicity and taciturnity.

I have sanitized the data through anonymization of my respondents. All the interviews were conducted with prior permission.

\section{Results and Discussions}

The disasters are one of the major culprits of millions of deaths and loss of properties worth billions in the human history (Stromberg, 2007). On annual average, 227.5 million people across the world become the victims of disaster (Rezwana, 2017). According to the National Society for Earthquake Technology (NSET), 42, 000 Nepalis have lost their lives to different disasters that occurred in the period of 1971 to 2017. These macro level data obscures the fact of unequal distribution of data corresponding to geography and to a set of social, economic characteristics of the victim population. Several global and local studies have shown that disasters hit the improvised population more than wealthy and affluent
(Cannon, 2002; Hannan, 2002), and, the disasters tilt more toward the female population in terms of their devastations (Enarson, 2002; Liang and Cao, 2014). Women and girls account for $55 \%$ of the total casualties of 2015 earthquake in Nepal (GoN, 2015).

Disasters are the incidents when gender-based relations of a society are overtly and covertly implicated. Patriarchy and unequal gender relations are rampant in the Nepali society (Bennett, 1983) much like elsewhere which correspond to the heightened vulnerability of women as compared to men (Rezwana, 2017). The accounts and issues of women in Gamchha are not earthquake-shaped; they are rather constructed through hundreds of years of patriarchal practices which reproduce worse effects during the time of disaster. The social and familial interaction between men and women are caused by socially constructed roles and duties, which, in turn, made its impact on the "interactive order" in the earthquake. During 2015 earthquake, the immediate response to move out of the structures was thwarted by the key socially constructed role of doing domestic chores.

As per the gendered script, on April 25, 2015, women and girls of Gamchha were busy cooking or serving food or washing utensils when the earthquake hit the country at the high noon. Even though there were no deaths in the locality, the domesticity of the female chores delayed many women and girls their exit from their mud houses, all of which were destroyed afterwards. The doing of gender (West and Zimmerman, 1987), which encapsulates the females within the domesticity, entails constructions which perpetuate at several occasions including disasters. In the day of earthquake, working women of Gamchha, most of who were working in the lowest rungs of modern employment chain, were dashing to finish the workloads of the whole week when the jolt shook their houses. Chandra Maya, a menial worker of weekdays, reminisces the day:

\footnotetext{
It's was a Saturday, holiday, but it's a burdened day for me. I am engaged in private sector office so I must have to complete my week-long chores in a day. I was in a rush because there were a lot of work to be done in a day such as preparing food, house cleaning, washing clothes of all my family members, and even work in the kitchen garden. I was washing utensils, all of a sudden plates and bowls started to shake. After a while, I realized it's an earthquake but I got confused where to go-stay inside or run out, when the walls shook I came out but with an injured leg.
}

A case of Chandra Maya is not merely contextualized to highlight, yet her experience resurfaces a conjectural effects of gender enmeshed with a host of matrices. The swift response to disasters is dawdled by the structural duties inside a family. A family is constituted of husband, wife and children. In cases of joint families, there are several other family members. When Gita was inside her home, she was multi-tasking - executing routine chores while her two year son was taking a nap.

During the earthquake, I was with my baby, inside the house. At once, my son squealed. There was a chore half accomplished, 
the son squealing, and the tremble. My husband was outside, I forgot where he was. I got confused, almost blacked out. In minutes, I pulled together. Taking my son, I rushed down the [wooden] stairs.

The sudden and momentous rush saved Gita and her son. But, it cost heavy afterwards. In the interview, she said of being lonesome and psychologically traumatic for months after the earthquake. At the face of cataclysm, she was facing death alone with a baby. The fact of her husband being outside could be termed as a mere chance of luck, but the same fact haunted her the most because all days she was alone inside the home taking care of baby and the chores. The fear of losing oneself and her son if she would have delayed some more seconds haunted several days ahead. This covertness of anxiety was shared by several women. These "would have beens" and "could have beens" are not the exteriors of any disaster research; these are the interiors which have the more concrete impacts on the lives of women. These chances of being alone inside the house during the high earthquake noon are the manifestations of patriarchy which relegates the women inside the house. Their lives enmeshed with the interiors of the houses became the chances for which they have to rush out while their husbands were already outside.

Not every women of Gamchha were unaware of the fact about the public memories of oft-repeated 1990 earthquake. In the towns and cities several programs were held on earthquake. Media frequently remembered the 1990 earthquake and alerted the general public about the forthcoming earthquake. The forthcoming earthquake was nowhere near to the women of Gamchha until it came suddenly. The place rarely got a chance to look at the earthquake preparedness programs as they were conducted as near as Kirtipur Bazaar, which was more than half an hour walk from the village.

An awareness program was held in the village for the first time two weeks before the earthquake. It was a rare occasion if being a presage of the impending disaster. The three day long program was conducted by the Nepal Red Cross Society and Lumanti Support Group for Shelter (LSGS). Apart from making aware the general public about precautions and responses, the program made the participants to take part in a drill. The program saw the overwhelming participation of male family members. My key informant was closely working with LSGS. That was the only program he could remember that was organized inside the village. According to him, there were several programs held in Kirtipur Bazaar, and there may be a few programs held along the main road [the road that goes from Kirtipur to Pushpa Lal Park], but there were none inside the village. The man informed all his male friends about the program. The participants were all men except some "curious" women whose husbands couldn't attend the program. The probe of the actual number of participants and their genders was futile. The patriarchal information sharing system is not an isolated incident as it is a norm for men to transmit information to men, and women don't receive information first hand from the experts (Genanet,
2004). The program in Gamchha, two weeks before the earthquake, was an impression of top-down and maledominated process of knowledge sharing.

Women are generally more likely to be injured or die than men during disasters (Neumayer and Plumper, 2007) because they are more exposed to risks (Fothergill, 1998). The socially constructed gendered behaviors put women at the greater risks by restricting their mobility. Many married women in Gamchha wear Sari. But, inside the houses, younger married women wear maxi, a skirt reaching to the ankle. This dress is worn both inside and outside of the houses. The sluggish nature of these dresses restricts women to get speed at the time of emergency. It is not general that all women wear Sari all the time, but almost all of the married women were wearing it when the earthquake struck. In the interview, Bandana (63), a Brahmin women, said even wearing Sari for so many years; she could not get a safe speed. She fell four steps of the staircase, broke her left hand when rushing out of the house. "This is it [showing to Sari she was wearing] that broke my arm. But, this is the only thing I wear."

There was not a single, more severe incident related to this cultural outfit, but there were genuine concerns that it slowed them down-leaving Bandana with a broken arm. The dress codes are themselves gendered-light and swift for men, they can run good in their pair of pants or pajamas; and, heavy and burdening for women. A sad repercussion of heavy, restraining and tangling dresses were observed in 2004 Boxing Day Tsunami in various different Asian countries (Neumayer and Plumper, 2007).

The Ministry of Health and Population (MoHP) has a network of 4, 118 health facilities. 19 percentages of them are located in the most affected districts (GoN, 2015). Approximately 250, 000 children from ages of six months to 59 months, and 135, 000 pregnant and lactating mothers were affected by earthquake. These women from the most hit regions faced the brunt of earthquake more severe than others. Women's reproductive statuses took a toll. Women from rural, poor backgrounds have already poor nutrition which seriously affects them while coping with hazards (Cannon, 2002). They are more prone to nutritional deficiencies because they pose unique demands especially when they are pregnant or lactating.

During the earthquake all the 135 houses were destroyed which get the red certificates. Even those partially destroyed mud houses were unfit to stay. As I took interviews in 2019, about four years after the earthquake, some families were still building houses. They were still living in huts with corrugated zinc rooftops. In the immediately set up tents, women complain their distressing days and nights. Their list of complain is long-the nutritious food was on the short supply and there were no beds for pregnant, lactating and elderlies. The health consequences of women during the time of earthquake are severe. The apparent fear of miscarriage loomed as the local women said whereas there might have real consequences like elsewhere (Paul et al, 2011). Nita talks about her pregnant daughter-in-law:

As she [daughter-in-law] was pregnant, we had to take extra care of her. She used to bumble around the tent. 
There was heap of hay here, wood plank there. She fell and almost hit her stomach. She said she didn't hit, but I think she hit the floor. We took her to the hospital only weeks after. I don't remember dates. But, she and her baby were fine.

The problem faced by the women and girls was the lack of proper hygiene during their menstruation periods. Given the social taboos, women had to relinquish their hygiene. The temporary shelters were difficult structures to get adjusted to their monthly cycles. Additionally, there was severe lack of privacy and sanitary pads. The shops were closed, the ladies worked out with pieces of clothes. The unhealthy use of cloths instead of pads could have ended with rashes and urinary tract infections (WHO, 2002). They complain that they didn't have enough waters in nearby taps, latrines being a far from the tents. The structures restricted the women's privacy - they were "ashamed" of drying their undergarments on the open sky.

As a mother of a daughter, Mina shared her experience vividlyWhen my daughter got her period, the other day of earthquake, she needed a pad, but there were none. We could have accessed the nearby shops but they didn't sell pads. She wrapped up with the pieces of my old clothes. Water was scarce. Drying panties was what do you say, nightmare. Above all, she had to walk and talk careful enough not to touch and be touched by anyone. Had she been a boy, would she have to go through the same way? You tell me."

The patriarchal hierarchies seem to be omnipresent. After the families started getting their individual huts instead of makeshift huts which were built just after the earthquake, the problems for women continued. The gender hierarchy crept unto bed hierarchies - that is, men occupied the beds and women had to sleep on floors. The cold enters the body easily in the makeshift huts than the proper houses. Healthy women started sneezing and coughing, and for senile and chronic, the situation deteriorated.

The Putuwar caste group Newars in Gamchha has a chronic history of being afflicted of tuberculosis (TB). During my first visit, when I stopped for a while to ask the local women about the way to go to Gamchha, they talked about TB killing them for a very long time. Why? They interpreted naively - they don't have money, they don't have information, they don't have education, they don't have anything, and they drink and smoke. Later, when I talked to Manju, a Putuwar women, who told me about the case of her grandmother who had afflicted by TB three years before the earthquake-

There were practically no beds. The available beds were not functioning - they were broken. We were all sleeping on the floor. On the third night she [grandmother] was having diarrhea. A TB patient, she used to writhe the whole nights with coughs. There were no health facilities, and nobody really cared as she was coughing for three years. Gradually, she became feeble and died. There are many old men and women who have taken TB tablets, and who have asthma. Everyone saw their bad nights after the earthquake.

The earthquake didn't spare the schoolgirls. Some of the girls, from the poor Putuwar caste, were forced to quit schools. The fate of schoolboys is not any better. The boys from the Putuwar community had a habit of leaving schools for jobs. Many opt for the helpers of the KirtipurRatnapark buses, others get jobs at different places like the nearby brick kilns. Before earthquake, girls were going to schools. In the Newar caste system, Putuwars are the touchable, unclean group, also known as dunyeeyans. As compared to high caste Newars, they have lower economic and social statuses. Culturally, there is a wide gulf between the Putuwar and other Newars (Nepali, 1965). Traditionally, they are hunters, bird catchers, fishermen, loggers, red clay carriers and wild planters (Toffin, 2008). They earn their livelihood as workers in stone quarries, selling firewood, as palanquin carriers, makers of flattened rice and the sellers of red social (Nepali, 1965; Toffin 2008). These occupational statuses of Putuwars show us that they live in the outlying locations of the Kathmandu Valley. In Gamchha, Putuwars are more into traditionally preparing and selling of rice popcorn and flattened rice in locations like Asan in Kathmandu and Patan in Lalitpur.

According to locals and my key informant, more girls than boys visited school before the earthquake. The earthquake shattered the dreams of the girls. There are no straight forward reasons that earthquake led to dropout, there is unique reason for each family. For example: Manu, a seventh grader, had to quit school and take care after her five year old brother as her mother and father have to work outside their home to make their ends meet and save some money each month to build the house.

The example of Manu reiterates a fact that women and girls from the poor families have to suffer disproportionately from disasters. Furthermore, local women commented that the duties entailed by their traditional roles were increased. As the locals comment that water, health and sanitation belongs to a female domain, they had a genuine concern for these facets of lives. Water is important in its own right, and equally important to health and sanitation. Urban and periurban women have to collect and save water for cooking, washing, cleaning and bathing among other tasks. The taps stopped working for weeks, and the Gamchha women had to walk up to the traditional taps close to the southern hillock. Even though the place is close to a major town, a so-called municipality, it still is rural in its many ways. Local Putuwar families don't always cook with petroleum gas, they have to collect firewood.

Another covert behavior women saw in their men members after the earthquake was the violence as a mode of idiomatic expression. In the context of violence, it is widely agreed that violence is erupted in cases of disruptive events more than more routine and habitual days (Stanage, 1974). It is not an argument that domestic violence erupted after the earthquake, but it catalyzed for the surfacing as the masculine burdens of taking care of the family came face-to-face with the men, which may have irritated to a greater degree. In my field interviews, I never came across fistical fights within the family members, but I was being informed about the episodes of "passive aggressiveness" when partners did their jobs, but were reluctant to talk to 
each other because of the anger and frustration within. My respondents couldn't fully express the mode of the symbolic violence, yet they would talk about "instigating anger" or talking violence rather than actually enacting it. However, Sita, a social worker, would talk about a wifebeating husband in the locality, and Shanti mentioned about scolding/beating episodes in the neighborhood. These claims were not established. There can be made a proposition from these interviews that there was not an ontological separation between verbal-and-symbolic violence, characterized by loud mouths or muted passive aggressiveness, and rare episodes when a husband gives a slap or picks up a stick, and quickly regrets (see: May, 1972). In the contexts of poor economic backgrounds, exacerbated during disasters where family members have to scrape by little resources, signaled violence and tongue-bashing may likely lead to physical violence like raising the hand to curse or threatening transforming unto a real hand on cheek. Based on my several interviews, I can face a safe fact that the burdening earthquake had irritated the husbands, and many may have increased their spirit consumption, and many were angered toward their fate, and the females were the fate personified and with whom they must have exchanged lingual violence and in rare cases they have slapped their wives.

Women and girls talked about the exchanges of stares and gestures with men during the immediate period where everyone of the village was staying in the same location sharing several tents. These were infinitesimal exchanges that irritated and threatened the girls, but many of my respondents like Sapana and Basanti claimed that the boys and men were making uncomfortable advances, which she calls them as a general harassment. Sapana told that in the temporary shelters the some boys and men talked about the sexual matters without a care who was passing by or who was closely sitting. Sapana:

In many occasions the talking group of boys would laugh when I passed by or walked around. I don't know what they laughed about. Was it about me? But, it really made me nervous. Am I exaggerating their boisterousness or in fact they are laughing at me? It was confusion, but I find it very unruly to laugh when a crowd of men laughs during a time of approaching lady or who is just passing by.

Sapana's feeling about the laughing boys intersects offence and morals, but it is a genuine concern that needs a note.

As I described the contextual features of experiences of women in a rural setting of Gamchha during earthquake in 2015, I want to touch upon the categorical features in which I describe the experiences of oppressed women whose familial and individual lives crisscross different categories in addition to being women which created the multiplier effect.

Recent literatures have accepted gender-class interface as a feature that exacerbates the vulnerability of women more than the single category (Fordham, 2011) while the class remained to be the basic categorical element in the analysis of disaster (Burton and Cuter, 2008). It has remained as a sociological truism that economically disadvantaged women often have to deal with the worst case scenarios.

In Gamchha, many economically backward families couldn't build their houses immediately. The amount of relief budget was meager, and the government provided the budget on piecemeal basis. The families had to build slapdash structures which were risky and were not completely cold resistant and didn't battle the rainwater. The availability of credits was almost impossible, and if it were possible, there remained anxieties that whether one can repay them back.

One female headed household, in which the husband is unstable, who is more of a carefree alcoholic than the househusband, was crushed by the economic burden, and faced the perpetual disaster (for global examples: Bradshaw, 1996; Laska et al, 2007). Nar Maya, a female head, with whom I interviewed said--

We were surviving by preparing and selling beaten rice and rice popcorns. Our house collapsed. I have a 5-year old daughter. And, I am the only working member of the family. The problem after I got was that I lost hope. You know...I aim to do a thing...say, dig this whole field, and, at the middle of work...I get too bored. Damn boredom, I worked at [that] kiln, and earn some money.

This Putuwar Newar household, which traditionally survives on selling rice popcorns, many of the community survive with short supply of unregistered lands, is failing to come up to shape even after four years of earthquake.

When I visited Gamchha, many women were sitting over the firewood ovens and in a community beaten rice mill. All the women hadn't seen school in their lives, and didn't know paperwork. The problem of Gamchha family is not the landlessness, but the unregistered nature of their land, which restricts them to legally sell their only asset.

The Putuwar community of Gamchha has a history of being inflicted by tuberculosis for a very long time. I don't have a quantified measure of life-expectancy of the community members. As I went to the village and talked to several women, they said that they are married early, before 20. Stiffened by early pregnancy, cold related chronic and bacterial diseases infect them. Already weakened, they faced additional hazards during the time of the tent and temporary stays. They too have lower literary, numeracy rates for men and women above 50 . The nearby private school is ten minutes' walk, and a government school is about half an hour. They have a high dropout rate. Burdened, boys used to leave school early and work in transportation, as helpers in buses and microbuses. After the earthquake, the familial situation became abstractamalgamation of psychological and economic hardship. According to her mother, Sushant had to quit school because,"I have two daughters; one is small, just a year old. After the quake, I must work...the job I got was of a domestic helper. Somebody had to look after the child at home. Sushant does that for me."

The impression of Gamchha, derived by interviews and the anecdotes, is that the women are silently crying for the problems they are suffering after the earthquake. The 
problems they are facing are mundanely exotic: at once one sees the women are mundanely enacting the same traditional roles after the earthquake, yet they are playing exotically worsened roles.

\section{Conclusion}

This study finding clearly shows that the experiences of women and girls are quite different from those of men. These experiences have long been overlooked and bracketed off during the bureaucratic process of disaster, and, likewise are conspicuously absent in academic literatures. This layered and differentiated nature of experience is pertinent to the women's reproductive health and longer home duties related to care and cooking. They have to waste longer hours and heightened problems on water, health and sanitation. As entered into women, the women of poor households have to face exacerbated problems with crunched cash and compromised health. This discriminatory effect of disaster is socially contrived and constructed, hence, entails a feminist and intersectional approach in all the processes, which are currently more top-down and male dominated, of disaster. This research calls the future research on disaster to sensitize issues with concepts including feminism to incorporate the differential experiences of women.

\section{Acknowledgment:}

I would like to thank Professor Madhusudan Subedi, Associate Professor Tikaram Gautam, and colleague Nirmal Acharya for reading the draft and providing me with valuable notes.

\section{Funding:}

This paper is based on my MA thesis "Women in Disaster: A Sociological Study of Vulnerabilities in 2015 Earthquake" which I carried out with UGC, Nepal fund. The UGC Master's Research Support award no.: MRS/74 75/H\&amp;S-01

\section{Ethical Conduct of Research:}

I declare that this paper is based on the research conducted ethically.

\section{References}

Adhikari, B. (2015). The great earthquake of 1934. New Spotlight Newsmagazine 8(22). Retrieved May 22, 2015 (https:// www.spotlightnepal.com/2015/05/19/the-great-earthquakeof-1934/).

Bennett, L. (1983). Dangerous wives and sacred daughters: social and symbolic roles of high-caste women in nepal. California University Press.

Bolin, B. (2007). Race, class, ethnicity and disaster vulnerability. In Handbooks of disaster research. H Rodrigrez, E.L.Quarantilli and R.R Dynes (eds). Springer.

Bradshaw, S. (2004). Socio-economic impacts of natural disasters: a gender analysis. United Nations Publications. Santiago Chile

Burton, C. \& Cutter, S. L.(2008). Levee failyres and social vulnerability in the sacremneto-sam joaquin delta area, califorina. Natural Hazards Review 9(3):13-30.

Cannon, T. (1994). Vulnerability analysis and the explanation of Natural Disasters, in Disasters. In Development and Environment. A Varley (ed), Jhon Wiley and Sons Ltd.

Cannon, T. (2002). Gender and climate hazards in Bangladesh. Gender and Development 10 (2): 45-50.

Crenshaw, K. W.(1989). Mapping the margins: Intersectionality, identity politics and violence against women of color. Originally published in Stanford Law Review vol.43.

Enarson, E. (2000). Gender and natural disasters. Recovery and Reconstruction Department.

Enarson, E. \& Brenda, P. (2008). Invitation to a new feminist disaster sociology: integrating feminist theory and methods. In Women and Disasters: From Theory to Practice. Brenda Phillips and B.H Morrow (eds). Washington DC: International Sociological Association Meeting.

Enarson, E. (2002). Gender issues in natural disasters: talking points on research needs. Crisis, women and other gender concerns. Working Paper, ILO, Geneva: 5-12.

Enarson, E. \& Morrow B. H. (1998). Women will rebuild miami: a case study of feminist response to disaster. The gendered terrain of disaster. E. Enarson and $\mathrm{BH}$ Morrow (eds).1998.:185-199

Finlay, L.(1998). Reflexivity: an essential component for all research? British Journal of Occupational Therapy 61(10): 453-456.

Fordham, M. (2011). Gender, sexuality and disaster. In The Routledge Handbook of Hazards and Disaster Risk Reduction.Ben Wisner, JC Gaillard and IlanKelman (eds). London: Routledge.

Fothergill, A. (1998). The Neglect of Gender in Disaster Work: An Overview of the Literature. The Gendered Terrain of Disaster: Through Women's Eyes. Praeger Publishers.

Genette, Gerard. (1980). Narrative Discourse. Ithaca. Cornell University Press.

Laska, Shirley, Betty. H. M., Beth.Wilinger, and Nacy. Mock. (2007). Gender and Disaster:Theoretical Considerations. In Katrina and the Women of New Orleans .B. Wilinger(ed). New Orleans: Newcomb College Center for Research on Women ,Tulane University (Available at www.academia.edu/.../ Chapter1.Gender and Disaster Theoretical Considerations).

Liang, Y \& Cao, S. (2014). Is the health status of female victims poorer than males in post-disaster construction in China: A comparative study of data on male victims in the first survey and double tracking survey data. BMC Women's Health, 14 (1): 18 .

McCall, L. (2005). The complexity of Intersectionality. Journal of women in culture and society30(3): 1771-1800.

National Planning Commission.(2015). Nepal earthquake 2015: post disaster needs assessment. Vol. A: key findings. government of Nepal, National Planning Commission. 2015.

Nepali, G. S. (1965). The Newars. United Asia Publications.

Nepal, P., Khanal, N. R. \& Pangali Sharma, B. P.. (2018). Policies and institutions for disaster risk management in Nepal: a review. The Geographical Journal of Nepal: 11: 1-24.

Neumayer, E. \& Plümper, T. (2007). The gendered nature of natural disasters: The Impact of Catastrophic Events on the Gender gap in Life Expectancy, 1981-2002. Annals of the Association of American Geographers 97(3):551-566.

Parkinson, D. (2011). Gender and Disaster. Victoria: Women's Health Goulburn North East.

Porta, D. D. \& Keating, M. eds.(2008). Apporaches And Methodologies In The Social Sciences. European University: Cambridge University Press.

Quarantelli, E. L. (1998). What Is a Disaster? Routledge.

Rezwana, N. (2014). Disasters, gender and access to healthcare: 
women in Coastal Bangladesh. Routledge

Stanage, S. (1974). Reason and violence. Littlefield/Adams.

Toffin, G. (2008). Newar society: city, village and periphery.

Himal Books, Social Science Baha.

Devi Gurung is a sociology graduate from the Central Department of Sociology, Tribhuvan University. She has earned her MA degree in 2019 with a dissertation titled "Women in Disaster: A Sociological Study of Vulnerabilities in 2015 Earthquake" with University Grant Commission Fellowship. She has worked in research programs on social inclusion and earthquake resilience organized by Central Department of Anthropology/USAID. She has written a few articles on topics of feminism and disaster in a Nepali language Currently, she is working with a childrenfocused German Organization, Namaste Homes, in Kathmandu.

Email: devigurung255@gmail.com 